\title{
ANALISIS STRATEGI DAN FEASIBILITY PENGEMBANGAN MRO PEMELIHARAAN ENGINE DI INDONESIA
}

\author{
Freddy Franciscus*, Ericko Chandra Utama \\ Prodi Teknik Penerbangan, Fakultas Teknologi Kedirgantaraan, \\ Universitas Dirgantara Marsekal Suryadarma \\ Komplek Bandara Halim Perdanakusuma, Jakarta 13610, Indonesia \\ ${ }^{*}$ Corresponding Author: freddyf60@rocketmail.com
}

\begin{abstract}
Abstrak - Bisnis pemeliharaan pesawat terbang di Indonesia masih sangat menarik sejalan dengan pertumbuhan jumlah pesawat terbang yang dimiliki maskapai domestik. Sekitar 65\% porsi biaya pemeliharaan pesawat terbang milik maskapai domestik belum terserap MRO Indonesia. Sebagian besar porsi yang belum terserap tersebut adalah klaster pemeliharaan engine dan komponen pesawat terbang, dimana hanya terserap sekitar 10\% (USD $100 \mathrm{Juta}$ ) dari 75\% (USD 750 Juta Th 2017) biaya pemeliharaan engine (35\%) dan komponen (45\%) pesawat terbang yang dikeluarkan oleh maskapai Indonesia. Dari serapan $10 \%$ biaya pemeliharaan engine dan komponen tersebut porsi serapan biaya pemeliharaan engine saja hanya 5\% (USD 50 Juta) dari 35\% (USD 350 Juta) biaya pemeliharaan engine. Masih ada sekitar 30\% (USD 300 Juta) yang merupakan peluang MRO Indonesia untuk mengembangkan capability pemeliharaan engine milik maskapai Indonesia. Dari beberapa tipe engine yang ada di maskapai Indonesia, CFM56-7B yang dipakai pesawat B737-800/900 mempunyai populasi terbanyak yaitu sekitar 450 engine. Hasil analisa feasibility terhadap pengembangan capability MRO engine untuk pemeliharaan CFM56-7B diperoleh hitungan ROI dan Pay Back Periodprogram pengembangan capability engine tersebut masing-masing adalah $24,57 \%$ dan 4.4 tahun dan nilai tersebut menunjukkan bahwa strategi pengembangan MRO engine CFM56-7B tersebut feasible.
\end{abstract}

Kata kunci : Feasibility, MRO, engine, ROI, PBP

Abstract - The aircraft maintenance business in Indonesia is still very attractive along with increasing number of aircraft on Indonesia airlines. As much as $65 \%$ of the aircraft maintenance costs of domestic airlines that have not been absorbed by MRO Indonesia. Most of the unabsorbed portions are aircraft engine and component maintenance clusters which only absorb about 10\% (USD 100 Million) of 75\% (USD 750 Million Th 2017) engine maintenance costs (35\%) and aircraft components (45\%), issued by Indonesian airlines. From the $10 \%$ uptake of engine maintenance costs and components, the portion of engine maintenance maintenance uptake is only 5\% (USD 50 Million) of 35\% (USD 350 Million) engine maintenance costs. There is still around 30\% (USD 300 Million) which is an opportunity for MRO Indonesia to develop the engine maintenance capability of Indonesian airlines. Based on several types of aircraft engines in Indonesian airlines, CFM56-7B used by B737-800/900 which has the largest population of around 450 engines. From the feasibility analysis on the development of the capability of the MRO engine for maintenance of the CFM56-7B, the ROI and Pay Back Period / PBP calculations for the capability engine development program are $24.57 \%$ and 4.4 years respectively. The ROI and PBP show that the CFM56-7B MRO engine development strategy is feasible.

Keywords : Feasibility, $M R O$, engine, $R O I, P B P$ 


\section{PENDAHULUAN}

\subsection{Latar Belakang}

Indonesia MRO Market 2015 - 2020
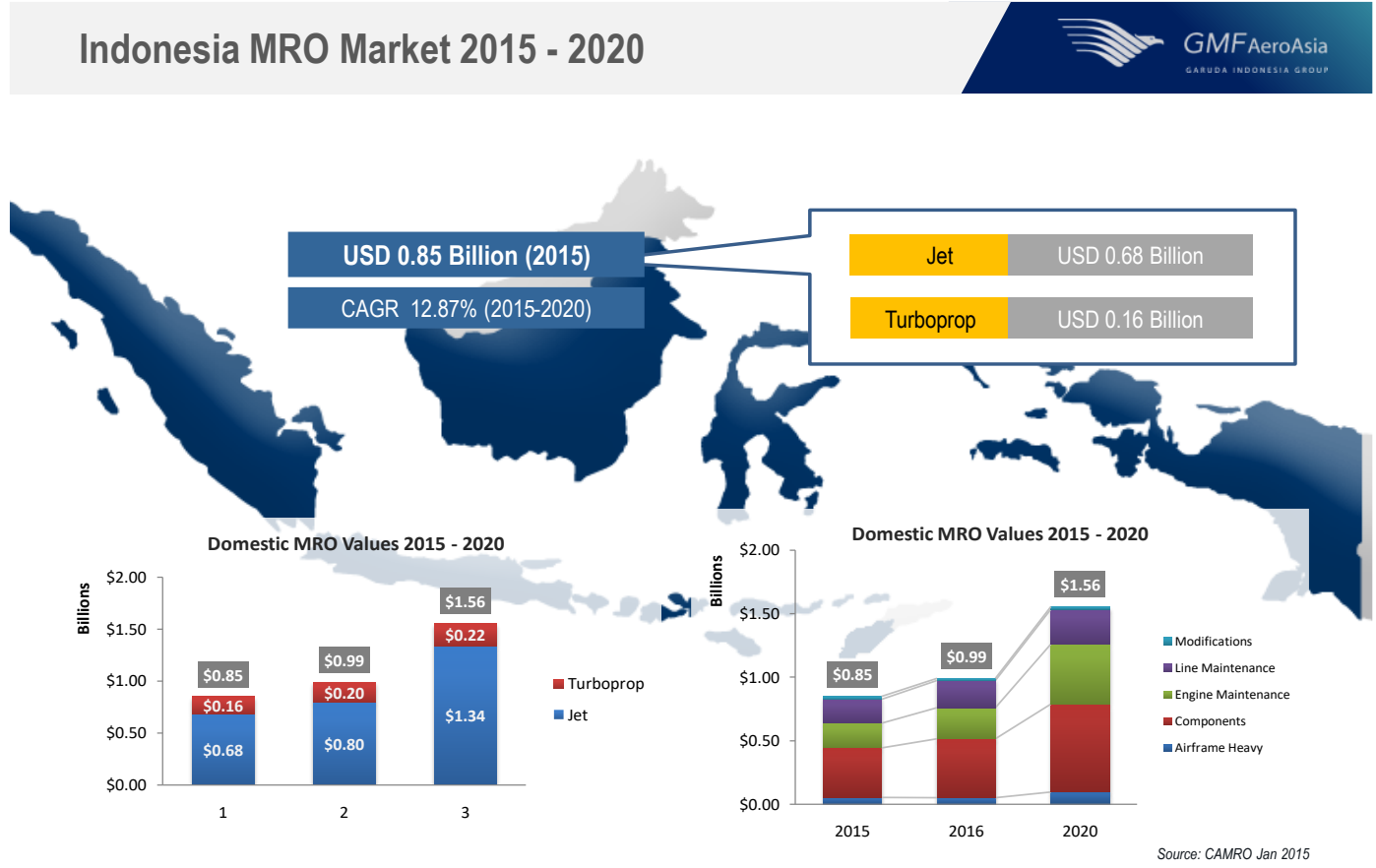

Gambar 1. Indonesia MRO Market 2015-2020[1]

Dari Gambar 1 Indonesia MRO Market 2015 - 2020[1] dan dari tulisan ilmiah di Jurnal Fakultas Teknologi Kedirgantaraan No. 1 Vol 3, Januari 2018, pada halaman 2 poin 1.1 Latar Belakang pada alinea terakhir dimana dijelaskan bahwa 'Klaster pemeliharaan engine dan komponen pesawat terbang adalah klaster yang masih minim penyerapan pendapatan nya oleh MRO di Indonesia yaitu hanya menyerap sekitar 10\% (USD 100 Juta) dari 75\% (USD 750 Juta Th 2019) biaya pemeliharaan engine dan komponen pesawat terbang yang dikeluarkan oleh maskapai Indonesia ${ }^{[2]}$. Dimana terlihat dari grafik di atas bahwa dari porsi $10 \%$ biaya pemeliharaan yang dapat diserap dari total $75 \%$ biaya pemeliharaan engine dan komponen tersebut, pemeliharaan engine hanya menyerap 5\% (USD 50 Juta) dari 35\% (USD 350 Juta) biaya pemeliharaan engine yang dikeluarkan oleh maskapai penerbangan Indonesia'. Karena minimnya daya serap MRO engine di Indonesia terhadap kebutuhan pemeliharaan engine milik maskapai Indonesia, maka untuk mengoptimalkan daya serap MRO engine di Indonesia perlu dilakukan kajian untuk meneliti dan menganalisa tentang tipe engine yang mana yang feasible untuk dibangun capability dan fasilitas MRO nya dalam usaha memperbesar daya serap biaya pemeliharaan engine pesawat terbang maskapai Indonesia.

\subsection{Permasalahan}

Total biaya untuk belanja pemeliharaan pesawat terbang milik 
maskapai Indonesia Tahun 2019 sekitar USD 1 Miliar. Sekitar 35\% dari total biaya tersebut yaitu USD 350 Juta adalah biaya untuk belanja pemeliharaan engine pesawat terbang. Sementara itu hanya sekitar $5 \%$ dari total biaya pemeliharaan tersebut yang bisa diserap oleh MRO engine Indonesia yaitu hanya sekitar USD 50 Juta. Masih ada sekitar USD 300 Juta yang belum terserap oleh MRO engine dalam negeri dan hal tersebut menjadi peluang dan sekaligus tantangan menarik buat MRO engine di Indonesia untuk mengambil porsi yang lebih besar dalam bisnis pemeliharaan engine pesawat terbang.

\section{PEMBAHASAN}

\subsection{Pesawat Dan Jet Engine Yang Dipakai Maskapai Berjadwal Indonesia}

Berdasarkan data-data 'Indonesia Aviation outlook 2017 by INACA' untuk jenis pesawat dan jet engine serta populasinya yang dimiliki maskapai di Indonesia, dapat di summary seperti pada Tabel 2.1.

Dari Tabel 2.1 terihat bahwa engine pesawat B737 800/900/MAX yaitu CFM567B adalah engine yang mempunyai populasi terbanyak di Indonesia yaitu sekitar 450 Engine.

Dari Tabel 2.1 terlihat bahwa tipe jet engine yang ada di maskapai Indonesia dan populasinya adalah sekitar 450 engine pesawat B737-800/900 (CFM56-7B), 120 engine pesawat $A 320$ (IAE-V2500), 110 engine pesawat $A 320$ (CFM56-5B), 38 engine pesawat $A 330-200 / 300$ (RR-800) dan 8 engine pesawat B777-300 (RR900). Dimana engine CFM56-7B yang mempunyai populasi terbanyak yaitu 450 engine. Sedangkan dari Tabel 2.2 dan 2.3 diperoleh perhitungan feasibility pengembangan MRO pemeliharaan engine CFM56-7B yaitu bahwa dengan ROI 24,57\% dan PBP 4,4 Tahun maka proyek pengembangan MRO engine tersebut sangat feasible walaupun dengan beberapa catatan yang harus diperhatikan.

Tabel 2.1 Beberapa Jenis Pesawat Jet Dan Type Enginenya Yang Dimiliki Maskapai Indonesia ${ }^{[3]}$

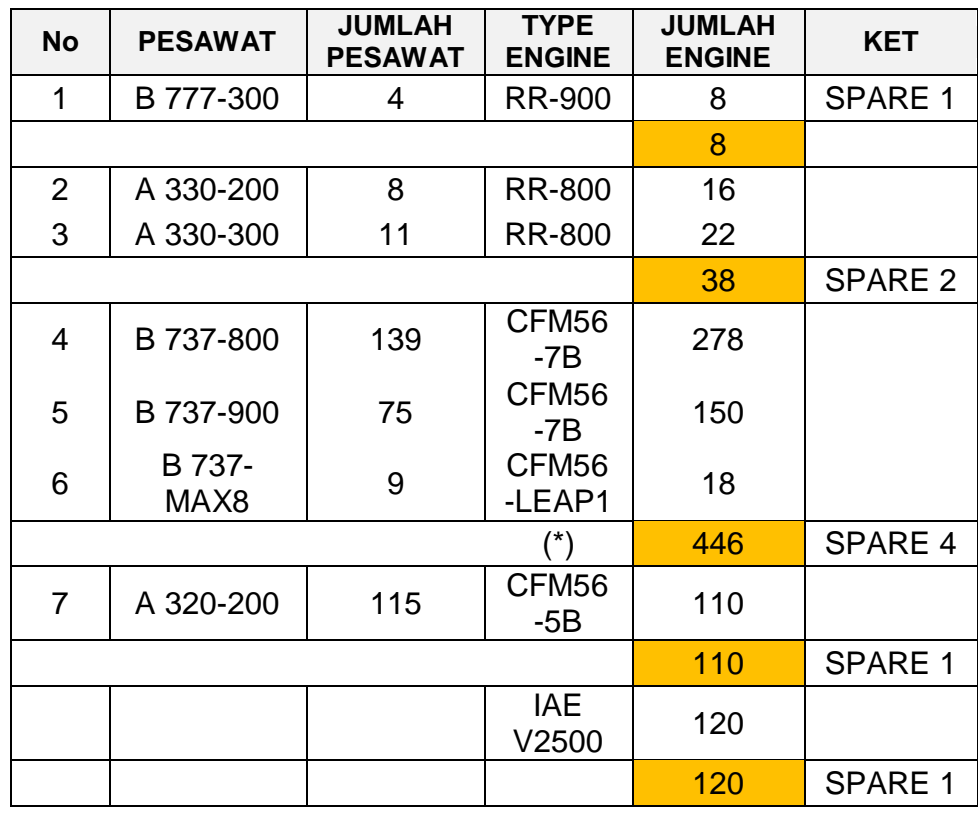

(*) Engine CFM 56-7B adalah engine yang mempunyai populasi terbanyak di Indonesia yaitu total sekitar 450 engine 


\subsection{Analisa Feasibility Pengembangan Capability MRO Engine}

Tabel 2.2 Proyeksi Pendapatan 5Th

\begin{tabular}{|c|c|c|c|c|c|c|c|c|}
\hline No & \multicolumn{3}{|c|}{ Pendapatan } & Tahun ke-1 & Tahun ke-2 & Tahun ke-3 & Tahun ke-4 & Tahun ke-5 \\
\hline 1 & \multicolumn{3}{|c|}{ Jasa Perawatan Engine CFM56-7B (Growth 10\%/Year) } & $\$ 180,000,000.00$ & $\$ 198,000,000.00$ & $\$ 217,800,000.00$ & $\$ 239,580,000.00$ & $\$ 263,538,000.00$ \\
\hline$\left({ }^{*}\right)$ & \multicolumn{8}{|c|}{ Asumsi Jumlah engine yang melakukan perawatan $10 \mathrm{EA} / \mathrm{BIn}$ dan Biaya perawatan USD $1.5 \mathrm{Juta} / \mathrm{Engine}$} \\
\hline 1 & $\begin{array}{l}\text { Peralatan } \\
\text { Engine Test Cell \& } \\
\text { Perlengkapannya }\end{array}$ & Jumlah & USD (X1 & & & & & \\
\hline 2 & $\begin{array}{l}\text { Tanah dan Bangunan dll } \\
\text { Total Investasi }\end{array}$ & 1 & $\begin{array}{r}\$ 1,000 \\
\$ 151,000\end{array}$ & & & & & \\
\hline
\end{tabular}

Tabel 2.3 Cash Flow Jasa Pemeliharaan Engine CFM 56-7B

\begin{tabular}{|c|c|c|c|c|c|}
\hline \multirow[b]{2}{*}{ Cash In } & Tahun ke-1 & Tahun ke-2 & Tahun ke-3 & Tahun ke-4 & Tahun ke-5 \\
\hline & & & & & \\
\hline Sindikasi Bank & $\$ 150,000,000.00$ & & & & \\
\hline Sub Total & & & & & \\
\hline \multirow{6}{*}{$\begin{array}{l}\text { Installment test cell }\left({ }^{*}\right) \\
\text { Sewa Kendaraan (50 mobil,@350US } \\
\text { Maintenance test cell (15\%) } \\
\text { Operation (listrik, air, fuel dll 10\%) } \\
\text { Salary (10\%) } \\
\text { Bangun Gedung dan Fasilitas Maint } \\
\text { Installment Bank } \\
\text { Biaya lain2 (3\%) }\end{array}$} & $\$ 30,900,000.00$ & $\$ 30,900,000.00$ & $\$ 30,900,000.00$ & $\$ 30,900,000.00$ & $\$ 30,900,000.00$ \\
\hline & $\$ 210,000.00$ & $\$ 210,000.00$ & $\$ 210,000.00$ & $\$ 210,000.00$ & $\$ 210,000.00$ \\
\hline & $\$ 18,000,000.00$ & $\$ 19,800,000.00$ & $\$ 21,780,000.00$ & $\$ 23,958,000.00$ & $\$ 26,353,800.00$ \\
\hline & $\$ 1,000,000.00$ & & & & \\
\hline & & $\$ 30,000,000.00$ & $\$ 30,000,000.00$ & $\$ 30,000,000.00$ & $\$ 30,000,000.00$ \\
\hline & $\$ 5,400,000.00$ & $\$ 5,940,000.00$ & $\$ 6,534,000.00$ & $\$ 7,187,400.00$ & $\$ 7,906,140.00$ \\
\hline Sub Total & $\$ 100,510,000.00$ & $\$ 136,350,000.00$ & $\$ 143,874,000.00$ & $\$ 152,150,400.00$ & $\$ 161,254,440.00$ \\
\hline EBITDA (Earning Before Int, tax \& dep) & $\$ 79,490,000.00$ & $\$ 61,650,000.00$ & $\$ 73,926,000.00$ & $\$ 87,429,600.00$ & $\$ 102,283,560.00$ \\
\hline Net Profit/EAITDA & $\$ 32,866,500.00$ & $\$ 17,702,500.00$ & $\$ 28,137,100.00$ & $\$ 39,615,160.00$ & $\$ 52,241,026.00$ \\
\hline$\left({ }^{*} \quad\right.$ Bunga Bank 3\%/Year & $\begin{array}{r}24.57 \% \\
4.40\end{array}$ & Th & & & \\
\hline
\end{tabular}




\subsection{Strategi Yang Harus Diperhatikan Dalam Pengembangan Capability MRO Engine}

Strategi penting yang harus dilakukan agar pengembangan MRO Engine dapat terlaksana dan sukses adalah:

1. Harus ada kerjasama konsorsium minimal antara dua maskapai besar di Indonesia yaitu Garuda Group dan Lion Group yang banyak memakai engine CFM56-7B pada pesawat B737-800/900/NG untuk mendirikan MRO Engine yang mempunyai capability lengkap

2. Lokasi MRO harus startegis sekitar airport dan berfungsi sebagai bonded area yang terintegrasi 'one stop solution'

3. Harus ada kerjasama yang baik antar kementrian terkait yaitu Kementrian Perhubngan, Kementrian Perindustrian, Kementrian Keuangan dan Kemeneg BUMN agar semua proses supply chain berjalan lancer

4. Bekerjasama dengan pabrikan Engine CFM56-7B yaitu General Electric untuk mendirikan MRO engine tersebut untuk mendapatkan approval dari pabrikan dan sekaligus sertifikat dari FAA

\section{KESIMPULAN DAN SARAN}

\subsection{Kesimpulan}

1. Engine CFM56-7B adalah engine yang mempunyai populasi jumlah terbesar di Maskapai Indonesia yang di pakai oleh pesawat B737800/900/MAX yaitu sejumlah sekitar 450 Engine. Jumlah tersebut sangat menggiurkan bagi MRO engine yang mempunyai capability pemeliharaan CFM56-7B
2. Dari hitungan feasibility pembangunan fasilitas MRO Engine CFM56-7B terlihat bahwa ROI nya 24,57\% dan PBP nya 4,4 Tahun dan hal tersebut menggambarkan bahwa pembangunan fasilitas MRO Engine CFM56-7B sangat feasible

3. Harus ada koordinasi dan sinkronisasi dengan kementriankementrian terkait dan juga dengan pabrikan CFM56-7B General Electric untuk membantu kelancaran dan perizinan membangun fasilitas MRO engine di bonded area sekitar airport internasional.

\subsection{Saran}

Perlu adanya kajian ilmiah lanjutan untuk menghitung dan menganalisa feasibility type engine yang lain yang populasi nya juga banyak. Selain itu juga perlu dilakukan kajian feasibility MRO komponen yang masih minim tingkat resapan terhadap pemeliharaan komponen pesawat terbang yang di miliki maskapai Indonesia.

\section{Ucapan Terima Kasih.}

Penelitian ini didukung oleh Unsurya berdasarkan Hibah Penelitian Internal di Tahun Akademik 2019-2020.

\section{DAFTAR PUSTAKA}

1. GMF Aeroasia, Opportunity of Cooperation, Seminar AMROI 12-13 Mei 2015

2. Franciscus, F., 2018, Review Strategi Pengembangan MRO di Indonesia, Jurnal Teknologi Kedirgantaraan, ISSN 2528-2778, Vol. 3 No. 1 Januari 2018, halm 1-5 
3. Indonesia National Air Carriers Association/INACA, 'Indonesia

Prospects

Ahead, Aviation Outlook 2017'

http://www.aviationweek.com, diakses pada 24 Mei 2018

4. Rusada Aviation MRO Technologies, How the MRO industry is investing in the next generation, Farnborough International Airshow, Aviation Industry June $26^{\text {th }} 2016$

5. Chausse, J., 2007, Building and Maintaining Engine Value, GEAviation

6. Derbex, A., 2017, CFM56 After Market Assessment: Strong

7. Viera, D. R., Loures, P. L., 2016, Maintenance, Repair and Overhaul (MRO) Fundamentals and Strategis : An Aeronautical Industry Overview, International Journal of Computer Applications, 0975-8887, Vol. 135 No. 12 Februari 2016.

8. County, R. B., 2016, Aircraft Repair Station Feasibility Study, Issued by : Better City, The Town of Rangely 